\section{THE SPANISH LONG-TERM CARE SYSTEM IN THE EUROPEAN CONTEXT}

\author{
Yolanda De la Fuente Robles \\ University of Jaén \\ ymfuente@ujaen.es \\ Eva Sotomayor Morales \\ University of Jaén \\ esotoma@ujaen.es
}

Citation/Cómo citar este artículo: De la Fuente Robles, Y. and Sotomayor Morales, E. (2015). "The Spanish Long-Term Care System in the European Context". Arbor, 191 (771): a206. doi: http://dx.doi.org/10.3989/arbor.2015.771n1008

Received: January 16, 2014. Accepted: July 25, 2014.

ABSTRACT: The recent exponential increase in the number of people in situations of dependency and demand for social, health and residential coverage in Europe currently presents a troubling demographic forecast. This article describes the peculiarities of the Spanish care model within the European context. In order to do this, we review previous analyses that show the differences in the dependency care in European countries, such as the form of residence of its beneficiaries or the capacity of social networks to meet their care needs. Then, we proceed to present the purposes underlying the Spanish legal framework, as well as its strengths and limitations. The findings suggest that the universal model implemented in Spain could serve as referent for the European context, although this depends on the social models of coexistence and prior context in which the dependency occurs.

KEYWORDS: Dependency Care; Aging; Personal Autonomy; Informal Caregivers; Legislative Analysis of Dependency.

\section{EL SISTEMA ESPAÑOL DE ATENCIÓN A LA DEPENDENCIA EN EL CONTEXTO EUROPEO}

Copyright: (C) 2015 CSIC. This is an open-access article distributed under the terms of the Creative Commons Attribution-Non Commercial (by-nc) Spain 3.0 License.
RESUMEN: Europa presenta en la actualidad unas previsiones demográficas preocupantes, incrementando exponencialmente el número de las personas en situación de dependencia y su demanda de cobertura social, sanitaria y residencial. En este contexto europeo, creemos oportuno destacar el modelo de atención español, señalando sus particularidades. Para ello, en primer lugar, hemos realizado una revisión de los análisis que profundizan en las divergencias de la atención a la dependencia en los países europeos, como la forma de residencia de este sector poblacional o la capacidad de las redes sociales de cubrir sus necesidades de atención. En segundo lugar, procedemos a exponer las pretensiones del marco legislativo español, así como sus fortalezas y limitaciones. Las conclusiones apuntan a que el modelo universal implantado en España pudiera ser un referente en el contexto europeo, aunque ello dependerá de sus modelos sociales de convivencia y el contexto previo en que se desenvuelva la dependencia.

PALABRAS CLAVE: Atención a la dependencia; envejecimiento; autonomía personal; cuidadores informales; análisis legislativo de la dependencia. 


\section{INTRODUCTION}

The progressive aging of population is a phenomenon intrinsically linked to economic prosperity that affects the whole of Europe, which is one of the first regions where aging notably increased throughout the twentieth century in the global context (Marshall, 2006; Sen, 1998). The answer to this problem since the devastating consequences augured by Thompson (1929), Notestein (1945) and Stolnitz (1964) were somewhat oriented to questioning the pillars of welfare models. These estimations, which had their origin in the theories of the demographic transition, had their continuity until the late twentieth century. A clear is example is the speech delivered by Jörg- Dietrich Hoppe at the annual meeting in May 2009 denouncing the infeasibility of the German health system. Hoppe's speech would become a war declaration, but triggered a change in the public and political messages of the rest of Western countries (Cuesta, Menéndez y Ugarte, 2011). Similarly, from the field of social and welfare services, some have questioned the traditional care model that aims at providing care services and increasing the quality of life of both disabled and older people. In general, most European countries have adopted the concept of dependency to encompass a wider group.

The term dependency is used in the European context depending on the different legal and welfare regulations. The Council of Europe defined dependency as "a state in which people are in need of assistance and/or significant support to perform the ordinary actions of everyday life due to lack or loss of physical, mental or intellectual autonomy" (Council of Europe, 1999). The WHO (Vázquez-Barquero, 2001, p. 12) in its International Classification of Functioning, Disability and Health (ICF), distinguishes two levels of disability: deficiency and activity limitations or restrictions in participation. The purpose of these definitions was to standardize worldwide treatment and support for people in situations of dependency and to highlight the "functionality" of the term (Casado, 2009).

However, in addition to its technical and pragmatic purpose of delimiting the beneficiaries of social policies, dependency is a socially constructed term with negative connotations in relation to the person in need of outpatient care (Walker, 1981). For example, in the Anglo-Saxon context, Wilkin (1987) and Wilkin and Thompson (1989) classify dependency in terms of the daily activities for which an individual depends on others, and in terms of the causes of dependency. Townsend (1981) has highlighted the concept of structured dependency and Hockey and James (1993), term life-cycle dependency.

Throughout this article, we will present the different contexts of dependency in Europe without considering individual European models, although we refer to studies that do, because our interest is to advance the knowledge of general trends in contrast with the Spanish system. And way of introduction, it should be noted that care for people with lack of personal autonomy has depended to some extent on the prior structure of health coverage and social services. Moreover, the characteristics of the diverse situations of dependency, such as social and cultural, also stand as influencing factors that influence the way in which informal care is provided, etc.

\section{EUROPEAN AND SPANISH DEMOGRAPHIC ESTIMATES}

The alarms generated by demographic estimates initially focused on the national level, and later gave way to the analysis of the problem in a European context, assuming the demands arising from this situation as new social risks (Taylor-Gooby, 2004). Thus, during the second half of the nineties it became clear that the challenges were common to all member states. In 1999, and as a contribution to the United Nations International Year of Older Persons, the European Commission presented a communication entitled "Towards a Europe for All Ages" (EU Commission [Comisión de las Comunidades Europeas], 1999) that pointed toward a closer cooperation among all member States and introduced a series of measures related to aging. It also joined the EC Treaty combating age discrimination (Article 13, as amended by the Treaty of Amsterdam) and a reference to the rights of the elderly was included in the Charter of Fundamental Rights (art. 21 and 25).

To date, the response from the European Union to aging has been inscribed within the framework of an overall strategy consisting of mutually reinforcing policies that aims to exploit the full potential of all citizens whatever their age, and is orientated towards policies and practices that promote active aging. But to realize this global strategy, it was necessary to project its execution in the same legislative competence in the field of older people, which relies almost exclusively on member states, since the role of the European Union basically involves supporting national policies and actions. ${ }^{1}$ 
In 2013, the estimations of the Global Index of Ageing expected people over 60 to account for over a fifth of the world population by 2050 . In 2012, the world population of this age group represented $11 \%$ of the world population; in 2013, it is estimated that this figure will reach $16 \%$; and $22 \%$ in $2050 .^{2}$ Globally, this data are a challenge and a hope since, while they can be a threat in the constitution of the population pyramid of economically advanced countries, they are a sign of increased life expectancy in poor countries.

In Europe, the trend is similar. A significant finding is the exponential increase in life expectancy at age 65 (average survival years expected from this age) in five years. In Spain, it went from 17.3 in 2005 to 18.7 in 2011. Other countries such as Finland showed data from 16.8 years in 2005 to 17.7 in 2011. France showed a figure of 17.7 in 2005 and 19.3 in 2011; and Germany, from 16.9 in 2005 to 18.2 in 2011. ${ }^{3}$ In short, there is a general tendency in all European countries to increase an average of 2-year survival in a period of 5 . This means an increase in the population group over 85 and therefore a general growth of the population with lack of personal autonomy (OECD, 2013).

As for the Spanish population in the global context, the estimates calculated that the percentage of population over 60 would increase from $6.5 \%$ in 2012 to $15.8 \%$ by $2050 .{ }^{4}$ At the start of the international economic crisis and coinciding with the years in which the Law for the Promotion of Personal Autonomy and Assistance to Dependent People (LAPAD) was implemented, the United Nations predicted that the Spanish population would decrease in 9.4 million by 2050 , representing $24 \%$ of net losses in the current population. According to these data Spain will be the fourth country with the highest percentage of senior population in the world after Japan, South Korea and Macao in 2050. This will mean that in that same year the group of citizens over 65 years may amount to $37 \%$ if current trends continue. The proportion of people aged 80 or older will increase to $12 \%$ in 2050 (VV. AA., 2011).

Thus, the aging of the population affects Europe as a whole, since as an integrative social context of participation of the elderly; Europe has been one of the first regions affected by aging throughout the twentieth century. Since these devastating consequences were predicted, the answer to this problem has evolved in several ways. At first, the political debates and answers focused on the national level. During the second half of the nineties, it became clear that the challenges were common to all Member States. However the case of Spain has developed in a particular way within the set of countries in the European Union.

Back to demographic data, the report Meeting Social Needs in an Ageing Society (2008) $)^{5}$ highlighted the effects of population growth through a population pyramid of 2008 along with the 2060 projection, showing that a stationary pyramid will change to the contracting one, which is characterized by low birth and mortality rates for decades. The sanitary conditions of the population allow life expectancy increases. In the projection of 2060 , over $35 \%$ of the Spanish population will be over 70 , compared with $12 \%$ under 20 years (Díaz Martín, 2008). According to the Statistical Yearbook of Spain (National Institute of Statistics [Instituto Nacional de Estadística], 2010), the total population in Spain in 2009 was 46,745,807; $6,793,975$ of which were aged 65 or older while 988 929 were 85 or older.

In order to differentiate the Spanish demographic tendency in the short (2018) and long term (2049), in 2008, the INE Report "Short Term Projection of the Population in Spain (2008-2018)" affirmed that the resident population in Spain would surpass the 49 million people in 2018 and anticipated a slowdown in the growth rate of the population of Spain from $1.8 \%$ per year in 2007 to $0.7 \%$ in 2010 .

Comparing the data rendered by the 2008 Spanish population pyramid and the estimate for $2018^{6}$ shows that births decrease by 2018 . On the other hand, the population under age 15 would increase by $13.1 \%$ (921,000 people), but the largest increase was expected in the age group over 64, which will grow by $19.2 \%$ in the next decade. This involves adding 1.44 million people in these ages to residents in Spain, and it could also be inferred that the Spanish population in 2018 would reach an average age of 40 , compared to the average of 30 that prevailed in 2008. Moreover, it was estimated that life expectancy would increase almost two years for males and 1.5 years for females.

It could be said that the regions with a more intense relative population growth in the next decade will be Castilla-La Mancha (17.5\%), Murcia (16.6\%), Balearic Islands (15,9\%) and Valencia (14.4\%). In contrast, population will decrease in Asturias (1.7\%), the Basque Country (1.3\%) and Galicia (1.2\%). The projected population of Spain in the long-term is a statistical simulation of the size and demographic struc- 
ture of the population residing in Spain in the next 40 years, if current demographic trends and behaviors continued (National Institute of Statistics [Instituto Nacional de Estadística], 2010). Current demographic tendencies would lead to a progressive decrease in population growth in the coming decades. The natural population growth would be negative since 2020 . The population over 64 years would double within 40 years and it would represent more than $30 \%$ of the total due to the aging of the population pyramid. The future population growth rates, which would increase from 2.1 million in the next 40 years, would be reduced. Thus, Spain would come close to 48 million in 2049. Population growth would gradually decrease in the coming decades. The simulation analysis also shows the progressive aging of Spanish society, which is clearly observed in the evolution of the population pyramid of Spain.?

The largest absolute and relative growth are experienced from age 64 , as it is estimated that the size of the group of people who are 64 or older will double, representing $31.9 \%$ of the total population of Spain. On the other hand, the 0-15 population group would increase by 157,000 people (2.2\%). However, the population group aged 16 to 64 would be diminished by more than half million individuals, $18.4 \%$ of its current volume. With all these data, the projection estimates that for every 10 working-age people, there would be almost nine potentially inactive persons (under 16 or over 64) residing in Spain in 2049. That is, the dependency ratio would rise to $89.6 \%$ from today's $47.8 \%$.

Furthermore, it is estimated that if the current pace of reducing the incidence of mortality by age on the Spanish population is maintained, life expectancy at birth would reach 84.3 years for males and 89.9 years for females in 2048; increasing to 6.5 and 5.8 years respectively from 2007 . However, the largest population size and an increasingly aging population structure would produce a continuous growth in the annual number of deaths. The natural growth (between births and deaths) would decrease after reaching its maximum in the last decades in 2008 , and would become negative from 2020, which would be a strong deterrent to population growth, although life expectancy at birth will reach 84.3 years for men and 89.9 years for women in 2048.

We need to point that some of the projections made in the 90's failed by not taking into account immigration data. The economic crisis as caused the return of immigrants to their countries of origin, which has notably reduced young population and added to the general aging of population in the host country. The crisis has also activated the migration of Spanish unemployed labor force to foreign countries. Projections estimate that 5.2 million people will leave Spain in the next 10 years and approximately 18.0 million would do it in the next 40 years. However, his tendency is also reduced due to the parallel reduction of young population in the Spanish population structure. In short, the continued aging process of the Spanish population structure is confirmed by the falling birth rates and the negative migration balance (National Institute of Statistics [Instituto Nacional de Estadística], 2012).

\section{THE SPANISH CONTEXT PRIOR TO DEPENDENCY}

\section{White Paper Estimations}

In 2005, according to data from the White Paper on Dependent Care (WPU), there were 1,125,190 dependents suffering a severe dependence in Spain. It was noted that although the prevalence of dependence was higher among people aged 65 and older, these situations roamed across the whole age structure of a population, and it is expected that the number of people disabled for daily activities would reach 3,504.562 in 2020. Until recently, care for dependents in Spain was provided basically by the family and at an informal level, since only $6.5 \%$ of the people who needed long-term care received support from social services (Álvarez, 2005). This care was provided especially by women (83\% of family caregivers) who, in most cases, were unable to carry out any remunerated work (Sosvilla Rivero, 2009). In short, there was social and demographic pressure to introduce a model that would meet the daily needs of the collective.

The White Paper essentially established the following conclusions (Caldera Sánchez-Capitán, 2011):

a) The report estimated that, upon completion of the full deployment of the system, there would be 3.2 million people affected by dependence and lack of personal autonomy in Spain.

b) The definition of dependency was established in grades and levels according to the classification by the World Health Organization and corresponding to the situation of each affected person. Three grades were established: moderate, severe and high dependency, each of them with two levels depending on the capabilities of each dependent person. 
c) The existing service network in Spain was insufficient to cater for such a large number of people and therefore a new impetus such as the one given by the law was necessary.

d) The best way to address the situation was to recognize an individual right of all citizens to receive services and benefits. That is, experts favored a system of universal coverage.

e) The report indicated that there were two possible ways to assist the dependent: through direct financial assistance to families or through the development of a portfolio of professional care services. Of course, both approaches could be combined.

f) From the economic point of view, public resources should be considered an investment, not an expense. The report detailed the benefits that a strong injection of public funds would provide for the development of an important economic sector and job creation, since the so-called return rate amounted to $0.7 \%$ on average, one of the highest rates in public investment.

g) From the point of view of employment, the report estimated that, where appropriate services to all those affected were provided; the new jobs created could reach 350,000.

Until 2005, public assistance was provided by the health system and social services with a clearly inadequate coverage and important differences between regions and between urban and rural areas. In Spain, only $3.14 \%$ of people over 65 had a home help service; $2.05 \%$ through telecare and $0.4 \%$ through a place at a day center; data clearly showing a lack of coverage of the needs of people in situations of dependency (Rodríguez Castedo, 2005).

Implementation of a dependency care system in Spain. Law 39/2006 as the fourth pillar of the Spanish welfare state

Protection for dependency in Spain was provided from different angles before the implementation of the current model supported by Law 39/2006, though not in a unified way. The Non-Contributory Benefits Law (1990), General Health Law (1986), Law 7/1985 and Law Regulating Local Regime introduced universal health benefits and represented a major advance in regional competitions of facilities and services for dependent people. Law 13/1982 for the Social Integration of the Disabled (LISMI), the respective regional laws, the State Assisted Plan for the Development of Basic Social Services Local
Communities (1988), the Gerontological Plan (1990) and the Interministerial Agreement for Socio-Sanitary Coordination (1993), activated attention devices to this group, but the results were marked by shortages in services and resources, unequal territorial distribution, and a strong subsidiary character (Rodriguez Rodríguez, 2006).

Thus, the Spanish public system of social services needed updating and improvement to become guarantor of the rights of citizens in this area of social protection, and thus respond to the new social problems of people in situations of dependency.

This is due to the unequal access to resources granted users through the different regional laws of social services. On the other hand, previous to Law $39 / 2006$, only a portion of the resources for people in situations of dependency were the competence of social services; the rest were scattered among social, health and employment (such as Active Income for Integration) that were designed and shared by nondependent users (Álvarez, 2005).

This was the challenge that the Law on Personal Autonomy and Dependent Care (Law 39 /2006, LAPAD) tried to meet in Spain. Since the implementation of this Law, dependent care became a challenge for the authorities, as a firm and sustained response was required that adapted to the current model of society (Benitez et al., 2009). It has also set a new stage for social services, which must try to respond to the need for dependent care and the promotion of personal autonomy, quality of life and equal opportunities.

In a way, the LAPAD has had a stimulating effect on the adaptation of regional laws to the new legal frame at the state level.

We believe it appropriate to make a brief reference to the decentralized structure of the Spanish state, in order to emphasize the importance of this law for regional social policies. Spain has undergone a radical process of territorial transformation of the state since the onset of democracy in 1978 that involves three aspects: decentralization, democratization and European integration.

With democratization, there was an unprecedented expansion of the public sector, development of the welfare state, and modernization of the Spanish public sector. Political decentralization established the State of Regional Autonomies, which transformed the old centralized state into a new one that is structured in different scales (local, regional, central and com- 
munitarian) that relate to each other under complex and changing forms (Solozábal, 1992). 17 regions and 2 autonomous cities were created, which has generated some setbacks and competence dysfunctions over the years. As Alonso explains this phenomenon in the following terms (2010, p. 11) "the new context of decentralization has required a major institutional renovation of public administration, with flexible bodies and agencies that are closer to citizens, and do not duplicate other services with the same or other administrations".

However, the territorial decentralization has also allowed management to be closer to citizens. The LAPAD therefore relies on its intention to get progressively closer to citizens through the process of power decentralization that has occurred in this area in the past three decades, which has enabled the regional entities to gain responsibilities in Social Assistance. When the Statutes of Autonomy were approved passed, the responsibility for social services was formally attributed to regional governments, and the different regional laws for social service provisions emerged (see Figure 1). The first generation was created between 1982 and 1992, beginning with the Basque Country and ending with Cantabria. A second stage began in the regional legislation on social services from 2006. The LAPAD marked a turning point in the legislation on social services, after which subsequent laws were con- sidered a "second generation " or in other words, the second legislative regulations on social services from the start of democracy.

The present legislation (second generation of regional legislation) includes the laws of regions such as Navarra, Cantabria, Catalonia, Galicia, the Basque Country, Aragon and the Balearic Islands, approved between 2006 and 2009. ${ }^{8}$ In them, we find a number of novel contributions that set the tone of what is being defined as a new model of delivery of social services (Casado and Fantova, 2007):

- The beginning of the implementation of the new universal model in the second laws of Madrid $^{9}$ and La Rioja, ${ }^{10}$ which provide benefits for certain low-cost primary care services.

- The Asturian Act ${ }^{11}$ provides guaranteed access to certain benefits under a subjective right and creates the areas of social services as a means of decentralization and proximity to the users of the services provided by the regional government.

- All second laws follow the pattern to structure the offer in two organizational levels: a first versatile level, and a second multi-purpose one that meets specific needs.

- Some laws specify the possibility of private management of publicly owned services. Thus the Galician law ${ }^{12}$ opens to private action. In the

Figure 1. Evolution of regional legislation on social services

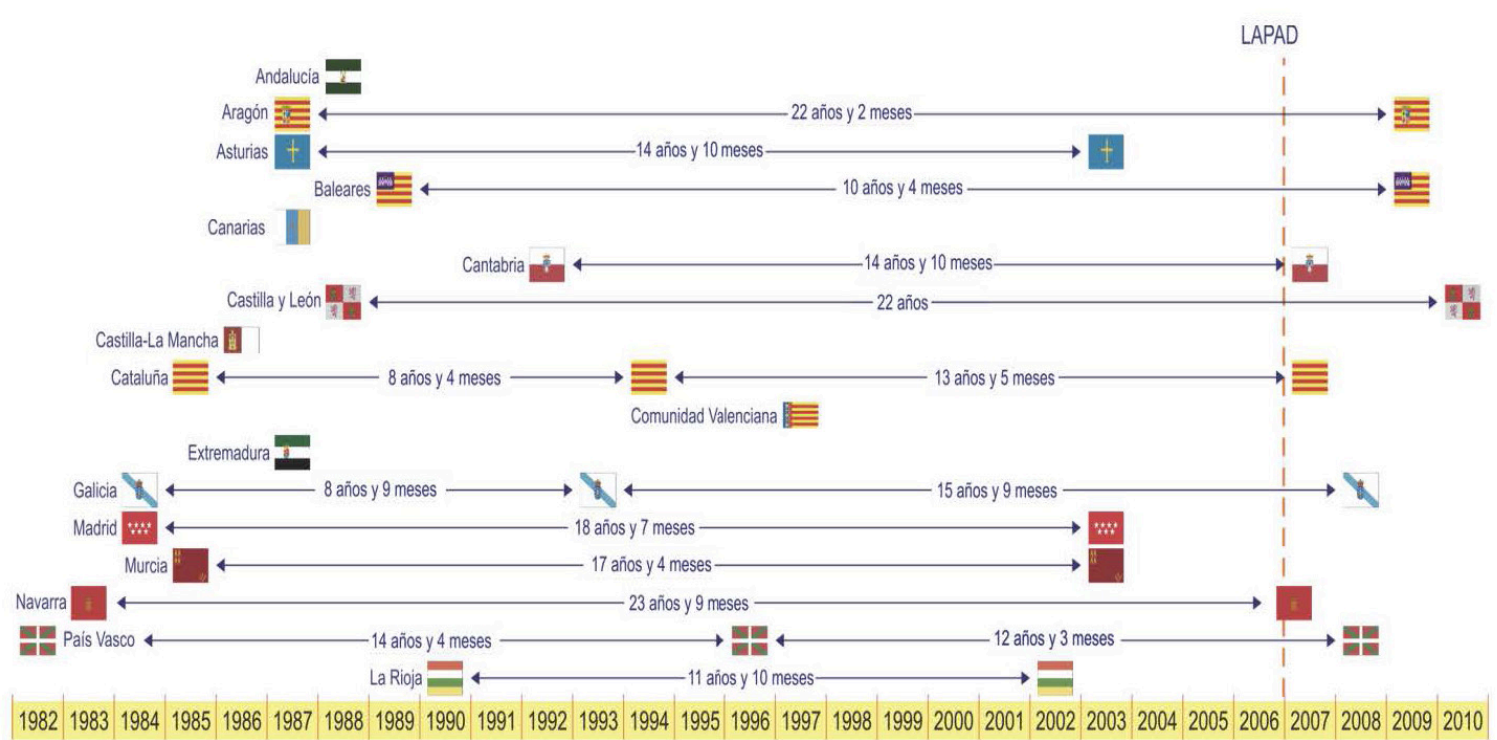

Source: Authors. 
same vein, the Basque law ${ }^{13}$ formula chooses to include in the public system, actions by publicly owned resources plus agreements with private providers (Casado and Fantova, 2007).

However, in relation with this process of adaptation of the regional rules to the law 39/2006, it should be noted that, firstly, it has been an uneven and open process since not all Autonomous Communities have reformed their statutes of autonomy nor have adopted new laws of social services. Not all the laws design the same models. The question is whether this diversity really allows personalized attention and the adequacy of services provided to the real needs of citizens, and whether it facilitates community involvement in solving their needs, without causing unjustified relevant differences in these terms. Secondly, we can say that we are facing significant legislative changes from an organizational and substantive point of view of rights. These changes affect the basic elements of the system, creating new trends that must be confirmed in the future, since the laws do not solve key outstanding issues that must be corroborated by development rules and budgets (Vila, 2011).

\section{TRENDS AND DIFFERENCES IN DEPENDENCY IN EUROPE}

As mentioned above, the aging of population is not a particular demographic phenomenon of Spain, but it affects Europe as a whole and, therefore, the "economically privileged" areas of the planet. The reasons that show a scenario that demands increasing attention to the needs of people with lack of personal autonomy are similar: increased life expectancy and decreasing birth rates. It is for this reason that European countries approach this issue from different angles that require higher public budgets for dependency, and an aging population demanding action at the health, social, urban and residential levels (Gaymu, Ekamper and Beets, 2007).

As previously noted, despite being a common situation, the aging phenomenon in the case of Spain is especially accelerated due to a marked increase in longevity. Proof of this is that in less than 30 years, the number of people over 65 has doubled, while birth rates dropped sharply since the mid- 70's (in 1975 , the average number of children was nearly 3 per woman at childbearing age, compared to current average of 1.2). ${ }^{14}$

The peculiarities in the European context are primarily determined by previous data and by factors that operate under dependent care policies that in the case of Spain, have started from a pernicious economic situation with an accelerating aging rate, but with advanced social policies that have sought to give a boost to these social demands. However these have been implemented in some of the most economically hard times in the history of Spain, the current crisis starting in autumn 2007, which has meant a decline in these policies, with special funding needs and other problems that will be discussed in the next section.

In order to make a comparison of the positions and characteristics of public policies in Europe with reference to the Spanish context, we wish to highlight the following aspects:

Firstly, the existence of uncertainties that complicate the picture of social policies and pension financing, which is uncertain for countries with an aging demographic profile and the evolution of the health of older people in a crisis context (Gaymu, Ekamper and Beets, 2007). Thus, the "quality of life" or the socalled "family well- being" (López Peláez and Segado, 2013) of people in situations of dependency in each European country is determined by the benefits and services available that allow them to apply for quality residential services, and care services that provide a certain autonomy at home. Because both services and benefits involve a high cost, the quality of life of this population depends on the maintenance of pensions on the one hand, and on the other hand, of their standard of living or the tendency to public policies to fund such services, hence predictions are not easy to make.

Also noteworthy is the influence of family attitudes to compensate the possible deficiencies of the welfare state or the lack of autonomy to meet the costs of dependent care (Gorjón and López Pelaez, 2013). In this sense, European countries suggest differing trends. While the Southern model points to intergenerational solidarity and "coresidence", the Northern model advocates institutional solutions and collective residence. The strong tendency of family solidarity described by Reher (1998) raises a question that affects the position of Spain concerning dependent care. This questions is whether the limited availability of infrastructure is actually caused by a high presence of intergenerational solidarity (Roussel, 1995), or on the contrary, it is precisely this lack of infrastructure that has forced the needs of people experiencing dependency to be assisted by their families. It seems that the studies conducted (Abellán and Esparza, 2009; Jacobzone, 2000; Riley and Riley, 1993) point to the uncorrelated presence 
of both factors. The attitude of the traditional family, particularly in rural areas (Losada, Knight and Márquez, 2003; Guzmán, Huenchuan and Montes de Oca, 2003) with its elders and dependents, and the strong social pressure, has not welcomed the institutionalization, or at least, has accepted it as the last resort (Vidal, et al., 1999). This also occurs in a geographical area in which the female labor, which has only existed from the 80 's, has been regarded as second rate, while the role assumed by women has been firstly, that of caregiver and responsible of caregiving and home, and only secondly, of remunerated worker (Sotomayor and Barroso, 2004). Social change has been dizzying in Spain, but socialization is highly influential while the generation from a previous social stage still survives.

Paradoxically, European countries at the beginning of the century have responded inversely, since countries with a tradition of intergenerational solidarity have invested on greater institutional coverage to soften the negative effects on caregivers; while countries with strong institutionalizing trends such as the Netherlands, have incentivized certain forms of family solidarity (Jacobzone, Cambois and Robine, 2000).

Policies aimed at promoting personal autonomy, care in the home to make advances in automation, and policies managing intergenerational solidarity, are being introduced in the European context, as the number of elders with children and who survive longer with their partners will increase faster than the elderly population as a whole (Gaymu, Ekamper and Beets, 2007).

On the other hand, dependent care does not relate only to social policies but also to health policies. As it was concluded in the European Forum for Primary Care ${ }^{15}$ it is urgent that national policies are oriented to coordinate social services and primary care. This is still a challenge in most European countries that operate in different fields addressing the same problem that affects dependent people in a multidimensional way: multimorbidity, frailty, disability and dependence. This lack of coordination is due in most cases to a lack of funding agreements between services (Boeckxstaens and de Graaf, 2011). In Spain, primary care has been supported in recent years by a highly profitable and efficient existing health system (Navarro, 2011), ${ }^{16}$ although at present, the debate on privatization and cuts policy is generating a loss of competitiveness (Bengoa, 2012). ${ }^{17}$ In addition, gerontology as a medical branch is established as a challenge, and most of care services for depen- dents come from social services, without dismissing the coordination efforts made by both institutions (Ahn, Meseguer and Herce, 2003).

Another area to note, in keeping with the theme of the vulnerability of dependents and the overload that their care could produce in the home environment, as already announced by the National Center on Elder Abuse (1998), is the abuse of seniors being generated in all European countries. Elder Abuse shows a progressive incidence and is expected to become one of the issues of greatest public concern in the coming years, which worsens with the low monitoring of social policies (Schiamberg and Gans, 2000; Papadopoulos and La Fontaine, 2000). Forms of abuse range from the psychological, which operates from the prevalence of $10.4 \%$ in Italy to $29.7 \%$ in Sweden and that is the way it acquires a higher incidence; following financial abuse, with an incidence of $1.8 \%$ in Sweden to 7.8 in Portugal. Finally, physical abuse gains more visibility but is only the tip of the iceberg with an incidence of $1 \%$ in Italy to $4 \%$ in Sweden, while Germany, Sweden and Lithuania show a high increase in prevalence rates of elder abuse. This must be examined by considering the visibility of the problem as a positive aspect that also causes rates of public denunciation and observation to increase, with the subsequent increase in its prevalence (Lindert, et al., 2013).

Continuing with care areas, there are significant disparities among the countries of the European Union in terms of long-term care. In general, the percentage of people receiving home help in OECD countries is higher than those receiving institutional care, but it is especially significant in Norway and the UK as well as in Austria and the Netherlands (See Table 1).

In Spain the situation is similar, but with the peculiarity that, along with the countries of the Mediterranean side, when care and support for the dependent person is not covered by the state, it has been provided by families and their informal caregivers (Jani-Le Bris, 1993; Jamieson, 1993; Twigg and Atkin, 1994; VV. AA., 1996; VV. AA., 2011; Salvage, 1995). However, the previously mentioned LAPAD has somewhat compensated this situation, even though the coverage level is still low.

In the twilight of the twentieth century, with the Law on the Social Integration of the Disabled, Spain had a privileged position in Europe by having systematic and administrative regulations in the field of disability, a situation which enjoyed very few countries in the European Union despite that they had broader 
Table 1. Percentage of people 65 and older who receive long-term care funded by public institutions or at home.

\begin{tabular}{|l|c|c|}
\hline Country (year) & Institutional Care & Home Care \\
\hline Sweden (2000) & 7.7 & 9.1 \\
\hline Norway (2000) & 6.0 & 18.0 \\
\hline United Kingdom (2002) & 5.1 & 20.0 \\
\hline Ireland (2000) & 4.6 & 5.0 \\
\hline Luxembourg (2001) & 3.8 & 4.2 \\
\hline Austria (2000) & 3.6 & 14.8 \\
\hline Germany (2003) & 3.6 & 6.5 \\
\hline Netherlands (2000) & 2.4 & 12.3 \\
\hline OECD (2000) & 4.8 & 9.1 \\
\hline
\end{tabular}

Source: Huber et al. 2005.

instrumental measures to protect dependents, but most without a unified approach. In these years, only Finland, Italy, France, Holland and Portugal had similar legislation, and the Swedish case with very specific rules and few isolated actions (Fantova, 1999).

At present, many countries have not developed legislation that meets the needs of this group yet, such as France, which has conducted numerous, though still insufficient, dependent care policies (Urteaga, 2012) for two fundamental reasons; firstly, because the measures implemented have failed to address the structural needs (increased aid applicant population and increased spending per user) and secondly, the economic and budgetary management of these needs.

After this review of the issues affecting the European reality and the territorial nuances that involve a need for social care policies for people in situations of dependency, it is observed that although there are national particularities, problems are common and comprehensive coverage of this population is necessary to avoid a high cost in the welfare of countries. In general, there is an accelerated increase in dependency ratios, especially in the Netherlands, who have gone from $27 \%$ in 1981 to $39.5 \%$ in 2000 ; or in countries such as Finland and Norway, reaching 5 to 7 percentage points. Nevertheless, it should be noted that there are dissimilarities in social tendencies, as while $40 \%$ of people over 65 live alone in the Nordic countries, in Mediterranean countries the percentage is almost the half of that figure, and this mainly affects the social coverage claimed by these people (Camacho, Rodríguez and Hernández, 2008).

What seems to have more impact is not the implementation of comprehensive measures of depen- dent care that include in an integral way, health and residential needs, caregiver support, accessibility and technical and assistive home care. The highest impact is caused by the funding of these measures, which already seem to be supported by sufficient scientific knowledge to determine which are the most appropriate.

The complex financial needs of this model have hindered its widespread deployment in Europe and this has led to a scenario with large disparities (Camacho, Rodríguez and Hernández, 2008).

\section{THE EVOLUTION OF THE DEPENDENCY SYSTEM IN SPAIN}

After this review of the areas of divergence and parallelisms in the European context, we believe timely to specify in the Spanish case. We will first analyze the set of benefits and beneficiaries of the LAPAD and its impact on employment; secondly, we will explore the difficulties arising from the decentralized model; and thirdly, some challenges related to specific groups. This is done in order to present the characteristics that have made the LAPAD an innovative policy in all European countries, with a special relevance of the pioneering role of the Scandinavian countries and the Netherlands throughout the nineties along with countries in continental Europe such as Austria, Germany, France and Luxembourg. These countries, have presented initiatives by which social rights are established in the area of long-term care, which have become the so-called "fourth pillar of the welfare state" (Rodríguez Castedo, 2005).

Having verified the progress in the care provided by the LAPAD to people in situations of dependency in Spain, it was particularly difficult to diagnose the effects of the legislative framework due to the fact 
that the figures of estimated applicants regarding the Law calculated in the aforementioned White Paper fell largely short.

But in terms of main achievements, it can be noted that, with regard to the interpretation of the disaggregated information on the beneficiaries, geographical environment and nationality, benefits by grade and employment, the data ${ }^{18}$ show that in 2011, the beneficiaries of the dependency benefits were mostly women (67\%). $63.83 \%$ of female beneficiaries were older than 80 , whereas men over 80 years are less than the half (40.78\%). Among people over 80 years entitled to a benefit for dependency, $76.28 \%$ - more than 3 out of 4 - already get it. There are currently 2,492 children under 3 in the system; $55 \%$ of them are male and most of them have a high rating grade (Grade III). ${ }^{19}$

In general, if we analyze the data by grade levels, we find that $14.49 \%$ of the beneficiaries are Grade III (level 2), 19.05\% are Grade III (level 1), 12.67\% are level II (level 2), 17.14\% are Grade II (level 1), 10.41\% are Grade I (level 2) and $13.17 \%$ are Grade I (level 1).

Most of the beneficiaries, $39.05 \%$ of the total, live in towns with over 50,000 inhabitants. However, about 200,000 beneficiaries reside in rural areas, which represent $28.50 \%$ of the total. The SAAD (System for Autonomy and Dependent Care) has facilitated benefit access to people living in rural areas.

As of January 1, 2011, 414,277 services were provided and 385,732 economic benefits were paid. Of the total economic benefits, 384,985 were aimed at family care, that is to say, $48.12 \%$ of the total. Residential care services are particularly appropriate for people with high dependency. Thus, one of four people with Grade III Level 2 receives this service (23.48\% of total), whereas only $8.83 \%$ of beneficiaries with Level 1 Grade II receive this service. There is a higher presence of males in non-residential services and economic benefits, and of females in residential services. This situation is supported by the fact that 93.5\% of non-professional caregivers registered for Social Security are women.

From January 2007 to December 2010, there were 260,406 new registrations for Social Security associated with dependence in the social services sector. With regard to the Special Collective Agreement of Non- Professional Dependent Caregivers, as of 03/01/2011, according to the General Treasury of the Social Security throughout the Spanish state, 154448 binding agreements and 824 volunteers had been resolved. From the resulting data we can deduce the apparent feminization of dependent caregiving (144,593 women and 9,855 men). The data show that, thanks to the implementation of the LA$P A D$, a large number of inactive people have gone into active status.

In Spain, in 2011, six per thousand people contributed to Social Security as employees or non-professional caregivers. Communities such as La Rioja, Andalusia, Cantabria, Castilla y León, and Castilla-La Mancha generated the largest employment and contributions in SAAD in relation to its population; while the Canary Islands, the Balearic Islands, Madrid and Valencia generated the least. If the backward communities reached the national average of beneficiaries of the total population, nine regions would create 12,779 new jobs and 32,043 new contributions would be guaranteed within the special collective agreement of non-professional caregivers. ${ }^{20}$

On January 2011, 127,977 workers were operating in the Network of Centers and Services of the System of Dependent Care, making this the only sector that has not destroyed jobs in times of crisis, but on the contrary, has generated and stabilized new jobs. As for non-profesional caregivers, the number of workers contributing through the Special Collective Agreement of Non-Professional Dependent Caregivers was 152,637 , only $39 \%$ of the total. Of these, $94 \%$ were women (45\% under $50,33 \%$ between 51 and 60 , and $22 \%$ over 60 years). That is, 127,977 jobs were stabilized in the SAAD, and 152,637 caregivers traded through special agreement on Social Security; which implies that the Dependency System generated 280,614 jobs and/or contributions to social security. ${ }^{21}$

Despite these data, the System of Dependent Care in Spain had several difficulties in its implementation that we will analyze in the paragraphs below since we consider that it might be of interest in order to provide a basis for reflection to promote the implementation of similar policies of dependent care.

In this sense, the main limitations of its development are determined by four major issues. Firstly, it was limited by the fact that it addresses social matters that are the responsibility of the regions. The law is accused of usurping regional powers and attacking regional autonomy. Secondly, it developed unevenly in the different regions, which caused conflicts of powers between the two levels of government and funding. Thirdly, the actual implementation of the 
law involves different executive and administrative levels, and interferes with the development of regional policies within a very complex political and institutional context.

Finally, we highlight the need for significant funding to generate the resources needed to carry out policy objectives such as assessing the needs and levels of dependency and the subsequent commissioning of the necessary services to grant due quality of life to dependent people (Ojeda and Ruiz, 2009).

These limitations have generated a political debate around the implementation of this System that is framed by a multilevel system. It is true that most public policies are developed today through multilayer structures and public action is rarely fully developed by a single territorial level of government. The real transformation of objectives through specific actions occurs locally and the officials responsible for implementing these actions can change them in different directions, which ultimately shows that the greater the number of actors involved in the implementation process, the less likely that the initial design will finally be carried out; therefore, the higher complexity, the higher difficulty for joint management. In light of the foregoing, it is evidenced that there is no democratic system where all the prerogatives of government rest on a single entity. This new form of public governance, where many public and private institutions are involved in the same program, imposes the need of coordination as a functional imperative.

The main problem is that the autonomous communities in Spain have assumed responsibility for social matters, which might lead to unequal treatment to dependent people by residence. On the other hand the state has absolute powers in matters of social security as a basic state benefits. Do not forget that the dependency system combines services and activities in various fields and that is what creates the problem: social services under the autonomous communities, and social security and IMSERSO under the General Administration of the state.

This whole network becomes more complex with the powers of local authorities who need to customize the responses but lack the human resources budget to do so. Considering that 7000 of the 8,100 Spanish municipalities have less than 5,000 inhabitants, we can deduce that this high number of small municipalities do not have sufficient resources to implement the measures envisaged by the national system of dependency. Three out of four dependents, that is; 2.8 million, live in rural areas characterized by an aging population of $11.7 \%$, nearly three points above the national average (National Institute of Statistics [Instituto Nacional de Estadística], 2012). In this situation, in which small municipalities are overwhelmed by the stress arising from high demand and the practical impossibility of covering, county councils ${ }^{22}$ could charge naturalization, so at first, it seems that high local fragmentation has been resolved with the intervention of councils. However it is not clear how far should their contribution get.

We would not wish to give the impression that the LAPAD and the system implemented in Spain has been a failure. On the contrary, believe that it meant a breakthrough in implementing comprehensive policies to dependent care. It is for this reason that after an analysis of its shortcomings, we will present what some authors consider to be the key to their success: Quality, Training, Collaboration and Control (De la Fuente and Sotomayor, 2007).

\section{CONCLUSIONS}

Today, we can say that the Law 39/2006 of 14 December on Personal Autonomy and Dependent Care has been a milestone in the field of the social policies implemented in Spain and a benchmark, with countries such as the Netherlands and Scandinavia, as an integral model of care in Europe. Although some support for dependents previously existed in Spain, the universal character conferred by this Law to the social rights of dependency places it within the overall framework of the European trend, in that it updates the legislative framework to the new needs of the population.

Previous to the implementation of this system, there were many limitations related to the high normative fragmentation regulating this area, the diversity of beneficiaries and social actors involved in the implementation of public social measures that were similar to the European context, although with certain peculiarities. Despite this progress, the system of dependent care generated by LAPAD has not met the objectives that inspired it. That is why we have tried to present its results and effects, its weaknesses and causes a few years after its implementation, as well as the improvements required for its future success. We did it with the necessary caution required to consider the socioeconomic context of the implementation of the Law, such as the cuts and delays in funding as a consequence of the Crisis, and the Royal Decree-Law 
$20 / 2012$, which is in some respects, a throwback to the philosophy inspiring the law, and some delays and loss of rights. However, we have not stopped at these recent changes because they are not the target of our analysis.

In short, we have explained how the LAPAD has been a breakthrough in two directions. Firstly, its coverage, because it is a highly demanded system with a wide range of demanding needs that exceed previous estimates, which shows the high degree of uncovered social problems fleeing Spanish social policies. And secondly, it is a system that promotes professional employment and non-professional caregivers even in an economically recessionary period.

As for the limitations and difficulties created by the Law, we have framed them within four areas. Firstly, it has generated jurisdictional problems between regional governments, local authorities and the central government. Secondly, it has been unevenly developed in different areas of the Spanish state. Thirdly, the actual implementation of the law involves different levels of government and administration, as well as the development of regional policies that mark a very complex political and institutional context. And finally, the development of the Law requires the necessary funding to provide the services as much as the human and logistical resources. After considering these limitations, it appears that its shortcomings are not the result of a weak design, but of the Spanish sociological context and its intrinsic features, in the territorial organization of the state and of economic factors such as the economic crisis affecting the funding possibilities of the Law.

The problem of women as dependent caregivers within the family, their training and their low social and economic recognition, has not been solved in an efficient manner in Spain yet (Segado and López Peláez, 2014).

Despite the rich content of the White Paper on the subject, the estimates of the potential beneficiaries of the law have fallen short and this has caused that the number of applications have surpassed expectations. The schedule designed by the system for autonomy and dependent care has not been met. Funding needs to cover the services and benefits generated by the law require financial solvency, which is difficult to solve in these times of crisis. Given the same degree of dependency, individuals have not received the same treatment in different autonomous communities and the application and decision process is long and complicated.

Despite the current situation of delays in the enforcement of the law, the disagreements between the regions and the state and the lack of funding, it is still necessary to have a comprehensive, global, and inclusive system of dependent care, in which the state assumes responsibility for the welfare of this collective. However, the process is expected to be long and difficult.

Thus the need for this integrated system and all its socio-political institutional fabric is certainly unquestionable. However, after six years of implementation, there seem to be certain faults in the coordination of regional and state administrations, and in the lack of qualified human resources to provide quality public services.

After these general considerations, we have analyzed the trends regarding the implementation of the policies of dependent care at European level, as can be seen in the table below.

In summary, in terms of trends and divergences of the Law, it may be noted that the demographic projections described in the first section point to a destabilization of the redistributive systems and the forecast of the unsustainability of the current pension systems in European countries. The changes will affect the social and economic situation of the dependent elderly due to lack of personal autonomy. At this level, intergenerational solidarity causes social problems that press on the lives and work of women, and the quality of dependent care, which causes a huge need to manage it in the different countries, both in terms of its presence and its lack.

On the other hand, institutional coordination in the social and health areas is a challenge for European countries that highlights the need to strengthen disciplines such as Gerontology, that give this social problem specificity and a multi-treatment.

It is evident that the group in a dependency situation generates for themselves and their environment a picture of social vulnerability that demands vigilance and pointed observation. The two major vulnerabilities that have been highlighted are the pressure towards non-professional female caregivers and the users of the system. A situation of social alarm is generated y interspersing both vulnerabilities in relation to the problem of elderly abuse that sometimes masquerades under a diagnosis of domestic violence 
Table 2. Trends and differences of dependency in Europe

\begin{tabular}{|c|c|c|c|c|c|c|c|}
\hline \multicolumn{8}{|c|}{ FIELDS OF ANALYSIS } \\
\hline & PENSIONS & $\begin{array}{l}\text { INTERGEN- } \\
\text { ERATIONAL } \\
\text { SOLIDARITY }\end{array}$ & $\begin{array}{l}\text { DEMOGRAPHIC } \\
\text { PROJECTIONS }\end{array}$ & $\begin{array}{l}\text { SERVICE COOR- } \\
\text { DINATION }\end{array}$ & $\begin{array}{l}\text { SOCIAL VUL- } \\
\text { NERABILITY }\end{array}$ & $\begin{array}{l}\text { LONG-TERM } \\
\text { CARE }\end{array}$ & $\begin{array}{l}\text { FUNDING } \\
\text { NEEDS }\end{array}$ \\
\hline 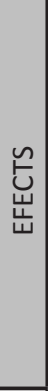 & $\begin{array}{l}\text { Uncertainty } \\
\text { in social and } \\
\text { health poli- } \\
\text { cies. Affects } \\
\text { the quality } \\
\text { of life of old- } \\
\text { er people. }\end{array}$ & $\begin{array}{l}\text { Compensate } \\
\text { for the short- } \\
\text { comings in } \\
\text { public poli- } \\
\text { cies. Social } \\
\text { problems in } \\
\text { the field of } \\
\text { gender in- } \\
\text { equality, vio- } \\
\text { lence, etc. }\end{array}$ & $\begin{array}{l}\text { Needs in terms } \\
\text { of personal } \\
\text { a u t o } \mathrm{n} \text { o } \mathrm{m} \mathrm{y}, \\
\text { residence and } \\
\text { managing in- } \\
\text { tergenerational } \\
\text { solidarity. }\end{array}$ & $\begin{array}{l}\text { The lack of } \\
\text { coordination } \\
\text { generates } \\
\text { non-holistic } \\
\text { dependency } \\
\text { treatment and } \\
\text { undermines } \\
\text { the effective- } \\
\text { ness of results. }\end{array}$ & $\begin{array}{l}\text { Strained care- } \\
\text { giver (with a } \\
\text { high preva- } \\
\text { lence of wom- } \\
\text { en) Effect in el- } \\
\text { derly abuse. }\end{array}$ & $\begin{array}{l}\text { When there is a } \\
\text { lack of policies } \\
\text { that strengthen } \\
\text { this area, there } \\
\text { is pressure on } \\
\text { the informal } \\
\text { care within the } \\
\text { family environ- } \\
\text { ment. }\end{array}$ & $\begin{array}{l}\text { A possible } \\
\mathrm{m} \text { i s } \mathrm{m} \text { a t } \mathrm{c} h \\
\text { between the } \\
\text { aims of the } \\
\text { systems of } \\
\mathrm{d} \text { e } \mathrm{p} \mathrm{n} \text { e } \mathrm{n} t \\
\text { care and lack } \\
\text { of funding. }\end{array}$ \\
\hline 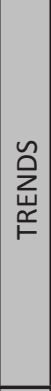 & $\begin{array}{l}\text { Reorganiza- } \\
\text { tion of na- } \\
\text { tional pen- } \\
\text { sion systems } \\
\text { for demo- } \\
\text { graphic esti- } \\
\text { mates. }\end{array}$ & $\begin{array}{l}\text { M a n a g ing } \\
\text { intergenera- } \\
\text { tional solidar- } \\
\text { ity in its pres- } \\
\text { ence or its } \\
\text { absence. }\end{array}$ & $\begin{array}{l}\text { The number } \\
\text { of elderly who } \\
\text { have children } \\
\text { and survive } \\
\text { with their } \\
\text { partner will in- } \\
\text { crease. There- } \\
\text { fore needs of } \\
\text { autonomy at } \\
\text { home increase. }\end{array}$ & $\begin{array}{l}\text { In general there } \\
\text { is a tendency to } \\
\text { uncoordinated } \\
\text { different insti- } \\
\text { tutional envi- } \\
\text { ronments and } \\
\text { poor develop- } \\
\text { ment of geron- } \\
\text { tology. }\end{array}$ & $\begin{array}{l}\text { Increase in cas- } \\
\text { es and social } \\
\text { alarm. }\end{array}$ & $\begin{array}{l}\text { Prevalence of } \\
\text { people receiv- } \\
\text { ing help at } \\
\text { home. }\end{array}$ & $\begin{array}{l}\text { Difficulty of } \\
\text { implementing } \\
\text { the measures } \\
\text { designed due } \\
\text { to complex fi- } \\
\text { nancial needs. }\end{array}$ \\
\hline $\begin{array}{l}\text { 出 } \\
\sum_{\breve{u}} \\
\text { 岀 } \\
\frac{u}{0}\end{array}$ & $\begin{array}{l}\text { S e r v i c e s } \\
\text { privatization } \\
\text { models ver- } \\
\text { sus universal } \\
\text { benefits. }\end{array}$ & $\begin{array}{l}\text { Intergen- } \\
\text { e rat i o n a I } \\
\text { solidarity and } \\
\text { coresidence } \\
\text { versus institu- } \\
\text { tionalization } \\
\text { and collective } \\
\text { residence. } \\
\text { Social context } \\
\text { of rural/urban } \\
\text { areas. }\end{array}$ & $\begin{array}{l}\text { Institutional- } \\
\text { ization versus } \\
\text { promotion of } \\
\text { personal au- } \\
\text { tonomy. }\end{array}$ & $\begin{array}{l}\text { Dependency } \\
\text { is approached } \\
\text { from a multi- } \\
\text { dimensional } \\
\text { point of view } \\
\text { versus lack of } \\
\text { coordination } \\
\text { due to a lack of } \\
\text { agreement on } \\
\text { the funding of } \\
\text { services. }\end{array}$ & $\begin{array}{l}\mathrm{Visibility} \\
\text { of problem } \\
\text { through moni- } \\
\text { toring of infor- } \\
\text { mal care and } \\
\text { training of the } \\
\text { caregiver/at- } \\
\text { tribution of } \\
\text { the problem } \\
\text { to other areas } \\
\text { such as domes- } \\
\text { tic violence. }\end{array}$ & $\begin{array}{l}\text { Institutional- } \\
\text { ization versus } \\
\text { long-term care } \\
\text { at home. }\end{array}$ & $\begin{array}{l}\text { Funding of } \\
\mathrm{m} \text { e a s u r e s } \\
\text { backed by sci- } \\
\text { entific knowl- } \\
\text { edge versus } \\
\text { cuts in the } \\
\text { measures. }\end{array}$ \\
\hline
\end{tabular}

Source: Authors.

but points to the consequences of extreme overload of informal caregivers. This points to the need to establish and strengthen the supervision and training of this group and the new field generated by new models (López Peláez and Segado, 2013).

The tendencies in the profiles of dependents point to the promotion of personal autonomy at home, in decrease of institutionalization. Long-term care is compatible with modern and accessible domotic systems by adapting new technologies to the needs of people with lack of autonomy.

In short, in the European context, member states are expected to adapt their systems to this type of comprehensive models despite the difficulties involved by a dissimilar start. Some countries have a larger number of people living alone at their own homes, while others are assisted residences or by their own families. The funding model is expensive, and this requires an effort in managing resources and above all, a synergy between European countries, which despite some differences, have a growing demand in dependent care. It is for this reason that we believe that the limitations of some countries in dependent care systems may involve an opportunity to implement more balanced systems that are adapted to the new realities for others. 


\section{NOTES}

1 Portal of European Seniors (Spain): http://www.mayoreseuropeos.eu/informacion_detail.htm?1

2 Source: UNDESA Population Division, Ageing and Development 2012, Wall Chart, 2012; UNDESA Population Division, World Population Prospects: the 2012 Revision, 2013.

3 Life expectancy at age 65, males. Source: OECD Health Data: Health status: OECD Health Statistics (database). 2013.

42013 Age Watch Spain Report. Age Watch International.

5 Along this chapter, we provide data from 2007, 2008 and 2009 in order to focus on the context previous to the design and implementation of the LAPAD, and the beginning of the international economic crisis.

6 Short-term population estimates (INE, 2008).

7 Long-term population estimates (INE, 2010).

8 See the current Social Services legislation in Spain in Bayarri i Catalán, and Fillat Delgado, (2011).

9 Law 11/2003 of 27 March, Social Services.

10 Law 7/2009 of 22 December, Social Services.

\section{REFERENCES}

Abellán García, A. and Esparza Catalán, C. (2009). Solidaridad familiar y dependencia entre las personas mayores. [On line]. [Date of consultation: $30 \mathrm{de}$ diciembre de 2011]. Available from: http://www.imsersomayores.csic.es/ documentos/documentos/pm-solidaridad-familiar.pdf

Ahn, N. Meseguer, J. A and Herce, J. A. (2003). Gasto sanitario y envejecimiento de la población en España. Documentos de trabajo, 7, Madrid: Fundación BBVA.

Alonso Sanz, I. (2010). La descentralización española y el Estado autonómico actual: una visión presupuestaria. Revista internacional de presupuesto público, 72.

Álvarez, M. (2005). Cuidados a las personas mayores en los hogares españoles. El entorno familiar. Madrid: Ministerio de Trabajo y Asuntos Sociales.
11 Law 1/2003 of 24 February, Social Services.

12 Law 13/2008 of 27 December, Social Services.

13 Law 12/2003 of 5 December, Social Services.

14 Report on aging. - General direction of the CSIC (Spanish National Research Council). November 2010. Available from http://www.fgcsic.es/files/adjuntos/InformeEnvejecimiento.pdf

15 European Forum for Primary Care, 2013. Available from http://www.euprimarycare.org/sites/default/files/EUR001_ annualplan_2013_draft_130110.pdf

16 Navarro, Vicent. "Los recortes en la sanidad pública". 14 November 2011. El plural.com. Available from http:// www.vnavarro.org/wp-content/uploads/2011/11/los-recortes-en-la-sanidad-pasblica.pdf

17 Bengoa, Rafael .Speech at Forum New Economy. Tribuna Euskadi. 15 Febrero 2012. Available from http://www.rafaelbengoa.com/2012/02/19/hay-soluciones-iii/

18 Data from the Ministry of Health, Social Policy and Equality "Statistics of the four years of implementation of the Lay of Dependency, 2011." Available from www.mspsi.es

Bayarri i Catalán, V. and Fillat Delgado, Y. (2011): Derechos y Servicios Sociales. Por un Sistema de Servicios Sociales universal, garantista y de calidad: un derecho básico para la igualdad y el desarrollo humano [on line]. Available from http://www.cermi.es/es-ES/ Biblioteca/Lists/Publicaciones/Attachments/254/DchosyServiciosSociales. pdf

Benítez Bermejo, E. J., Poveda Puente, R., Bollaín Pastor, C., Porcar Seder, R. M., Sánchez Lacuesta, J. J. and Prat Pastor, J. M. (2009). El sistema estatal de atención sociosanitaria en el ámbito de la dependencia. El caso español y otros modelos de referencia. Valencia: Universidad Politécnica de Valencia.

Boeckxstaens, P. and de Graaf, P. (2011). Primary care and care for old persons: Position Paper of the European Forum
19 The LAPAD distinguishes three grades of dependency: (a) Grade III or high dependency (b) Grade II or severe dependency and (c) Grade I or moderate dependency. Each of these established grades of dependency includes two sublevels depending on the autonomy of individuals and the intensity of care required. However, the implementation of the Royal Decree-Law 20/2012, of 13 July, on the measures to guarantee budget stability and promotion of competitiveness, a new structure is established that maintains the three grades that classify situations of dependency while it eliminates the levels.

20 "Aproximación al empleo estable generado por el SAAD y cotizaciones a la Seguridad Social de los cuidadores familiares", Asociación de Directoras y Gerentes de Servicios Sociales de España, 2011

21 Taking into account that non-professional caregivers cannot be counted as employees, we counted them through data from the General Treasury of Social Security (d. 1 January 2011).

22 Organ of government and autonomous administration of the province, recognized as such in Article 141.1 of the Spanish Constitution and is constituted by the President and the representatives (Legal Encyclopedia).

for Primary Care. Quality in Primary Care, 19 , pp. 369-89.

Caldera Sánchez-Capitán, J. (2011). Un tiempo para la igualdad. Madrid: Turpial.

Camacho, J. A., Rodríguez, M. and Hernández, M. (2008). El sistema de atención a la dependencia en España: evaluación y comparación con otros países europeos. Cuadernos geográficos, 42, 1, pp. 37-52.

Casado, D. and Fantova, F. (coords.) (2007). Perfeccionamiento de los servicios sociales en España. Informe con ocasión de la ley sobre autonomía y dependencia. Madrid: Fundación Fomento de Estudios Sociales y de Sociología Aplicada, FOESSA. Caritas Española Editores.

Casado, D. (2009). Respuestas a la dependencia anteriores a la Ley sobre la 
misma. En: Arriba González de Durana, A y Moreno Fuentes, F. J. El tratamiento de la dependencia en los regímenes de bienestar europeos contemporáneos. Madrid: Ministerio de Sanidad y Política Social, pp. 257-281.

Comisión de las Comunidades Europeas (1999). Hacia una Europa para todas las edades. Fomentar la prosperidad y la solidaridad entre las generaciones. [On line]. [Date of consultation: 24 november de 2013]. Available from: http:// europa.eu/legislation_summaries/employment_and_social_policy/disability_and_old_age/c11308_es.htm

Council of Europe (1999). Recent Demographic Developments in Europa. Estrasburgo: Publicaciones del Consejo de Europa.

Cuesta Cambra, U., Menéndez, T. and Ugarte, A. (coords.) (2011). Comunicación y salud: nuevos escenarios y tendencias. Madrid: Editorial Complutense.

De la Fuente Robles, Y. M. y Sotomayor Morales, E. M. (2007). Implantación y aplicabilidad de la Ley de Promoción de la Autonomía Personal y Atención a las Personas en Situación de Dependencia: Una reflexión sobre el contexto de Andalucía. Portularia, VII, 1-2, pp. 203-216.

Díaz Martín, R. (coord.) (2008). Informe 2008. Las personas mayores en España. Datos Etadísticos Estatales y por Comunidades Autónomas. Madrid: Ministerio de Educación, Política Social y Deporte. Available from: http://www.imserso.es/ InterPresent2/groups/imserso/documents/binario/infppmm2008.pdf

Fantova, F. (1999). Investigación y desarrollo de un modelo de gestión para organizaciones no lucrativas de servicios sociales [Tesis doctoral inédita]. Universidad de Deusto: Bilbao.

Gaymu J., Ekamper, P. and Beets, G. (2007). Who will be caring for Europe's dependent elders in 2030? Population., 4 (62), pp.675-706. http://dx.doi.org/10.3917/ pope.704.0675

Gómez García, J. M., Peláez Fermoso, F. J., González González, Y. and García González, A. (2008). Efectos sobre la generación de empleo del Sistema de Atención a la Dependencia: una estimación para Castilla y León. [On line] [Date of consultation: 11 de mayo de 2011]. Available from: http://www. uv.es/asepuma/XVI/114.pdf
Gorjón Gómez, F. and López Peláez, A. (coords.) (2013). Estado del Arte de la Mediación. Pamplona: Aranzadi

Guzmán, J. M., Huenchuan, S. and Montes de Oca, V. (2003). Redes de apoyo social de las personas mayores: marco conceptual. Notas de población, 77, pp. 35-70.

Hockey, J. and James, A. (1993). Growing up and growing old. Ageing and dependency in the life course. Londres: Sage.

Hubert, M., Hennessy, P. Lundsgaard, J., Izumi, J. and Kim, W. (2005). Long-Term care for older persons: eligibility, recipients and expenditure. Health Working Papers. Paris: OCDE.

Instituto Nacional de Estadística (2010). Proyección de la Población de España a largo plazo, 2009-2049. [On line]. Available from: www.ine.es/prensa/np587.pdf

Instituto Nacional de Estadística (INE) (2012). Proyecciones de población a largo plazo. Cifras de Población y Censos Demográficos. [On line]. Available from: http://www.ine.es/metodologia/ t20/t2030251_2009.pdf

Jacobzone, S. (2000). Coping with aging: internacional challenges. Health $A f$ fairs, 19, 3, pp. 213-225. http://dx.doi. $\operatorname{org} / 10.1377 /$ hlthaff.19.3.213

Jacobzone, S; Cambois, E. and Robine J. M. (2000). Is the health of older persons in OECD countries improving fast enough to compensate for population ageing?, OECD Economic Studies, 30, pp. 149190

Jamieson, A. (1993). Atención informal en Europa. In Comparación de políticas europeas de atención a las personas ancianas. Barcelona: SG editores.

Jani-Le Bris, H. (1993). Prise en charge familiale des dépendants âgées dans les pays del Communautés. Dublín: Fondation Européene pour l'amélioration des conditions de vie et de travail.

Lindert, J., de Luna, J., Torres González, F., Barros. H., Ioannidi-Kopolou, E., Melchiorre, M. G., Stankunas, M., Macassa, G. and Soares, J. F. (2013). Abuse and neglect of older persons in seven countries in Europe: a cross-sectional community study. International Journal Public Health, 58, pp. 121-132. http:// dx.doi.org/10.1007/s00038-012-0388-3

López Peláez, A. and Segado Sánchez-Cabezudo, S. (2013). La mediación en el Trabajo Social: aspectos relacionales.
En: Gorjón Gómez, F. and López Peláez, A. (coords.). Estado del Arte de la Mediación. Pamplona: Aranzadi, pp. 125-146.

López Peláez, A. and Segado SánchezCabezudo, S (2013). Empowerment, Well-Being and the Welfare State: Family Social Work in Spain. In Family WellBeing. European Perspectives. London: Springer, pp. 277-302. http://dx.doi. org/10.1007/978-94-007-4354-0 14

Losada, A., Knight, B. G. and Márquez, M. (2003). Barreras cognitivas para el cuidado de personas mayores dependientes. Influencia de las variables socioculturales. Revista Española de Geriatría y Gerontología, 38, 2, pp. 116123. http://dx.doi.org/10.1016/S0211139x(03)74867-7

Marshall, J. (2006). Life extension research: An analysis of contemporary biological theories and ethical issues. Medicine, Health Care and Philosophy, 9, pp. 8796. http://dx.doi.org/10.1007/s11019005-2668-7

National Center on Elder Abuse (1998). The national elder abuse. Incidence study. Final report. [on line]. Available from http://aoa.gov/AoA_Programs/Elder_ Rights/Elder_Abuse/docs/ABuseReport_Full.pdf

Notestein, F. W. (1945). Population-the long view. In Schultz, T. W. (ed.), Food for the World, Chicago: University of Chicago Press, pp. 36-57.

OECD (2013). Health a glance 2013: OECD indicators. [On line]. Available from: http://www.oecd.org/health/healthsystems/health-at-a-glance.htm

Ojeda, R. and Ruiz, S. (2009). Aproximación a la política pública de autonomía y atención a la dependencia: la necesidad hecha virtud. In de la Fuente, Y. (coord.). Situaciones de dependencia y derecho a la autonomía: una aproximación multidisciplinar. Madrid: Alianza Editorial.

Pacolet, J., Bouten, R., Lanoye, H. and Versiek, K. (1999). Social protection for dependency in old age in the $15 \mathrm{EU}$ Member States and Norway. Luxembourg: Office for Official Publications of the European Communities.

Pagán Rodriguez R. and Perez S. (2012). Depression and Self-Reported Disability among People in Westtern Europe. Journal of Aging and Health, 24, 7, pp. 1131-1156. 
Papadopoulos, A. Y. and La Fontaine, J. (2000). Elder Abuse. Therapeutic Perspectivas in Practice. Oxon: Winslow Press.

Reher, D. S. (1998). Family ties in Western Europe: Persistent contrasts. Population and Development Review, 24, 2, pp. 203-234.

Riley, M. W. and Riley, J. W. (1993). Connections: kin and cohort. In Bergtson, V. L. and Achenbaum, W. A. (eds.). The changing contract across generations. Nueva York: A. de Gruyter, pp. 169-189.

Rodríguez Castedo, A. (dir.) (2005). Atención a las personas en situación de dependencia en España. Libro Blanco. Madrid: Ministerio de Trabajo y Asuntos Sociales.

Rodríguez Rodríguez, P. (2006). El sistema de servicios sociales español y las necesidades derivadas de la atención a la dependencia. Madrid: Fundación Alternativas.

Roussel, L. (1995). La solidaridad intergeneracional. Ensayo de perspectivas. Revista Española de Investigaciones Sociológicas, 70, pp. 11-24. http://dx.doi. org/10.2307/40183798

Salvage, A. (1995). Who will care? Future prospects for family care of older people in the European Union. Luxemburg: Office for Official Publications of the European Communities.

Schiamberg, L. B. and Gans, D. M. (2000). Elder abuse by adult children: An applied ecological framework for understanding contextual risk factors and the intergenerational character of quality of life. International Journal of Aging \& Human Development, 50, 4, pp. 329359. http://dx.doi.org/10.2190/DXAX8TJ9-RG5K-MPU5

Segado Sánchez-Cabezudo, S. and López Peláez, A. (2014). Social work with middle-class Spanish families: The challenge of the work-family conflict. International Journal of Social Welfare 23, pp. 100-111. http://dx.doi. org/10.1111/ijsw.12012
Sen, A. (1998). Desigualdad y desempleo en la Europa contemporánea. Revista Internacional del Trabajo, 136, 2, pp. 155-172.

Solozábal, J. J. (1992). Sobre el Estado autonómico español. Revista de Estudios Políticos (Nueva Época), 78, pp, 105-129.

Sosvilla Rivero, S. (2009). Un análisis estratégico del sistema para la autonomía y atención a la dependencia. Presupuesto y Gasto Público, 55, pp. 7-29.

Sotomayor Morales, E. M. and Barroso Benítez, I. (2004). El dilema del acceso a los espacios sociales en la nueva sociedad global: una perspectiva de género. In de la Fuente Robles, Y. M. (ed.) El papel de la mujer en el voluntariado. Jaén: Universidad de Jaén. Servicio de Publicaciones e Intercambio, pp. 199-215.

Stolnitz, G. J. (1964). The demographic transition: from high to low birth rates and death rates. In Freedman, R. (ed.), Population: the Vital Revolution, New York: Anchor Books, pp. 30-46.

Tarabini-Castellani Aznar, M. (2007). Los requisitos para ser beneficiarios de los servicios y prestaciones de atención a la dependencia. In Roqueta Buj, R. (coord.). El sistema para la autonomía y atención de la dependencia. Encuentros y desencuentros con la Seguridad Social. Madrid: Ministerio de Trabajo e Inmigración, pp. 32-50.

Taylor-Gooby, P. (2004). New Risk and Social Change. En Taylor-Gooby, P. (ed.) New Risks, New Welfare: The Transformation of the European Welfare State. Oxford: Oxford University Press.

Thompson, W. S. (1929). Population. The American Journal of Sociology, 34, 6, pp. 959-975. http://dx.doi. org/10.1086/214874

Townsend, P. (1981). The structured dependency of the elderly: a creation of social policy in the twentieth century. Ageing and Society, 1, pp. 5-28. http://dx.doi. org/10.1017/S0144686X81000020
Twigg, J. and Atkin, K. (1994). Carers perceived: Policy and practice in informal care. Open University Press.

Urteaga E. (2012). El quinto pilar de la protección social: la política de dependencia en Francia. Cuadernos de Trabajo Social, 25, 1, pp. 221-235.

Vázquez-Barquero, J. L. (coord.). (2001). Clasificación Internacional del Funcionamiento, de la Discapacidad y de la Salud (CIF). Madrid: Ministerio de Trabajo y Asuntos Sociales.

Vidal Gutiérrez, D., Zavala Gutiérrez, M., Castro Salas, M. Quiroga López, P. y Klaasen Pinto, G. (1989) El significado del paciente con demencia para el cuidador, en una comunidad urbana y rural. Revista de Servicio Social, 1, 2. Available from http://www2.udec.cl/ ssrevi/ numero2/articulos/significado.htm

Vilà, A. (2011). Las leyes de servicios sociales del siglo XXI. Análisis jurídico-administrativo. Ponencia de las $\mathrm{X}$ jornadas del SIPOSO (Seminario de Intervención $y$ Políticas Sociales). Madrid: Polibea.

VV. AA. (1996). Protéger les personnes âgées dependantes. Des politiques en mutation. París: Organisation de Coopération et Développement Economiques (OCDE).

VV. AA. (2011). El futuro de la población. Información Estadística y Cartográfica de Andalucía (IECA), 1.

Walker, A. (1981). Towards a political economy of old age. Ageing and Society, 1, pp. 73-94. http://dx.doi.org/10.1017/ S0144686X81000056

Wilkin, D. (1987). Conceptual problems in dependency research. Social Science and Medicine, 24, 10, pp. 867873. http://dx.doi.org/10.1016/02779536(87)90188-2

Wilkin, D. and Thompson, C. (1989). Users' Guide to Dependency Measures for Elderly People. Sheffield: University of Sheffield, Joint Unit for Social Services Research. 